\title{
Down syndrome as a cause of abnormalities in the craniofacial region: A systematic literature review
}

\author{
Natalia Kaczorowska, ${ }^{1, A-D}$, Kamil Kaczorowski, ${ }^{2, E, F}$, Joanna Laskowska ${ }^{1, C D}$, Marcin Mikulewicz ${ }^{1, A, E, F}$ \\ 1 Department of Dentofacial Orthopaedics and Orthodontics, Division of Facial Abnormalities, Wroclaw Medical University, Poland \\ 2 Department of Ophthalmology, Kalmedica, Kalisz, Poland \\ A - research concept and design; $B$ - collection and/or assembly of data; $C$ - data analysis and interpretation; \\ $D$ - writing the article; $E$ - critical revision of the article; $F$ - final approval of the article
}

\section{Address for correspondence \\ Natalia Kaczorowska}

E-mail: nataliakaczorowskaa@gmail.com

Funding sources

None declared

Conflict of interest

None declared

Received on April 7, 2019

Reviewed on June 6, 2019

Accepted on July 30,2019

Published online on November 26, 2019

\begin{abstract}
Down syndrome (DS) is the most often diagnosed chromosomal disorder in newborns. The incidence is 1:792 live births. The article describes the irregularities and characteristics found in trisomy 21 , which greatly affect the functioning of the stomatognathic system. The most significant disorders include the following: false macroglossia, muscular hypotonia and gothic palate. These abnormalities affect articulation, breathing, food intake, and swallowing. We analyzed the morphological characteristics of the craniofacial region in children with DS based on the current literature review. The following databases were used for the analysis: MEDLINE (via PubMed), Scopus, Infona, and Dentistry \& Oral Sciences Source. In the course of the study, 199 pieces of literature were analyzed; the analysis also included 18 articles on children and adults with DS. It also took into account the structure of the palate, dental and skeletal defects, size of the tongue, muscular hypotonia, and temporomandibular joint dysfunction. Down syndrome is still a current subject of research. Although macroglossia, hypotonia, malocclusion, and temporomandibular joint abnormalities are not features exclusive to DS, numerous dysfunctions and parafunctions as well as retarded psychomotor development greatly complicate the treatment. Therefore, interdisciplinary treatment of patients with trisomy 21 and early treatment in the first months of life with the use of the Castillo-Morales plate are very important, as they ensure better adaptation to the subsequently used apparatus and reduce the risk of disorders of the stomatognathic system.
\end{abstract}

Key words: Down syndrome, hypotonia, dental defects, false macroglossia, Castillo-Morales plate

Cite as

Kaczorowska N, Kaczorowski K, Laskowska J, Mikulewicz M. Down syndrome as a cause of abnormalities in the craniofacial region: A systematic literature review. Adv Clin Exp Med. 2019;28(11):1587-1592. doi:10.17219/acem/112785

DOI

10.17219/acem/112785

\section{Copyright}

Copyright by Author(s)

This is an article distributed under the terms of the

Creative Commons Attribution 3.0 Unported (CC BY 3.0)

(https://creativecommons.org/licenses/by/3.0/) 
Down syndrome (DS) was named after John Langdon Down, a British doctor who first described its features in 1866. In 1959, a French doctor Jerome Lejuene identified the cause of this anomaly. The estimated incidence is 1:792 live births. ${ }^{1}$ The disorders in persons with DS include mental retardation, unfused lumbar vertebral arches and heart defects, among others.

The facial skeleton and neurocranium include hypoplastic mandible ${ }^{2}$ with reduced nasolabial angle, reduced dimensions of the permanent teeth ${ }^{3}$ and more frequent occurrence of periodontal diseases as compared to the neurotypical group. ${ }^{4}$ Malocclusion resulting from vertical and transverse irregularities of the dental arches is more frequent in patients with trisomy $21 .{ }^{5}$ This affects, among others, the demastication and texture of food, swallowing, articulation, and breathing. The abovementioned features are not pathognomonic symptoms.

Orthodontic abnormalities require early treatment of people with trisomy 21 . It is mainly conditioned by macroglossia and reduced volume of the palate. These features along with retarded psychosomatic development and muscular hypotonia lead to the occurrence of parafunctions and dysfunctions, which in turn affect the frequency of malocclusions in this group of people. The most clearly marked defect is skeletal class III, which is more severe in older age groups. This affects the lengthening of the lower part of the face and irregularities in the proportions of the facial skeleton. ${ }^{6}$

Muscular hypotonia is characteristic of trisomy 21. Most commonly, it affects the tongue and lips, which is visible on physical examination. Muscles lifting the mandible show different degrees of muscular insufficiency, but in the case of bruxism, severe hypotonia of the masseter muscles can be observed.?

The objective of this paper was to analyze the morphological characteristics of persons with DS, i.e., the palate, dental defects, skeletal defects, muscular hypotonia, temporomandibular joint abnormalities, and size of the tongue.

\section{Material and methods}

Non-randomized controlled trials (NRCT), systematic reviews (SR) and case series (CS) with sample sizes of 16 or more patients published since 1986, without any restriction in language or publication status, were eligible for inclusion in this review and were considered in our study. Children and adults with DS were matched in terms of age and gender with patients without DS. There was no restriction for the presenting malocclusion, indication for treatment or type of orthodontic treatment undertaken. Studies that investigated malocclusion, temporomandibular joints, measurement macroglossia, hypotonia, and hard palate were reviewed.

Comparison of the outcomes between 2 groups was performed: $1^{\text {st }}$ group - patients with DS; $2^{\text {nd }}$ group - patients without DS. All of the following symptoms were taken into consideration: tongue thrusting, abnormal breathing, eating disorders, lisping, and infantile swallowing.

The following databases were searched from January 24, 2018 to February 12, 2018:

- MEDLINE (via Pubmed),

- Scopus,

- Infona,

- and Dentistry \& Oral Sciences Source,

using the following Medical Subject Heading terms:

- Down syndrome,

- dental defects,

- trisomy,

- hypotonia,

- malocclusion,

- macroglossia,

- Castillo-Morales.

The search strategy for PubMed is presented in Table 1. At first, the potentially appropriate studies were identified

Table 1. Search strategy

\begin{tabular}{|c|c|c|}
\hline \multicolumn{3}{|c|}{$\begin{array}{l}\text { PubMed/MEDLINE, Scopus, Infona, Dentistry } \\
\text { \& Oral Sciences Source }\end{array}$} \\
\hline $\begin{array}{l}\text { Search } \\
\text { No. }\end{array}$ & Search & \\
\hline 1. & ((Down syndrome) AND hypotonia) & 185 \\
\hline 2. & $\begin{array}{l}\text { ((Down syndrome) AND macroglossia) } \\
\text { AND hypotonia }\end{array}$ & 6 \\
\hline 3. & $\begin{array}{l}\text { (((trisomy) AND dental defects) OR malocclusion) } \\
\text { AND Castillo-Morales }\end{array}$ & 1 \\
\hline 4. & $\begin{array}{l}\text { ((Down syndrome) AND hypotonia) } \\
\text { AND malocclusion }\end{array}$ & 1 \\
\hline 5. & (Castillo-Morales) AND hypotonia & 6 \\
\hline
\end{tabular}

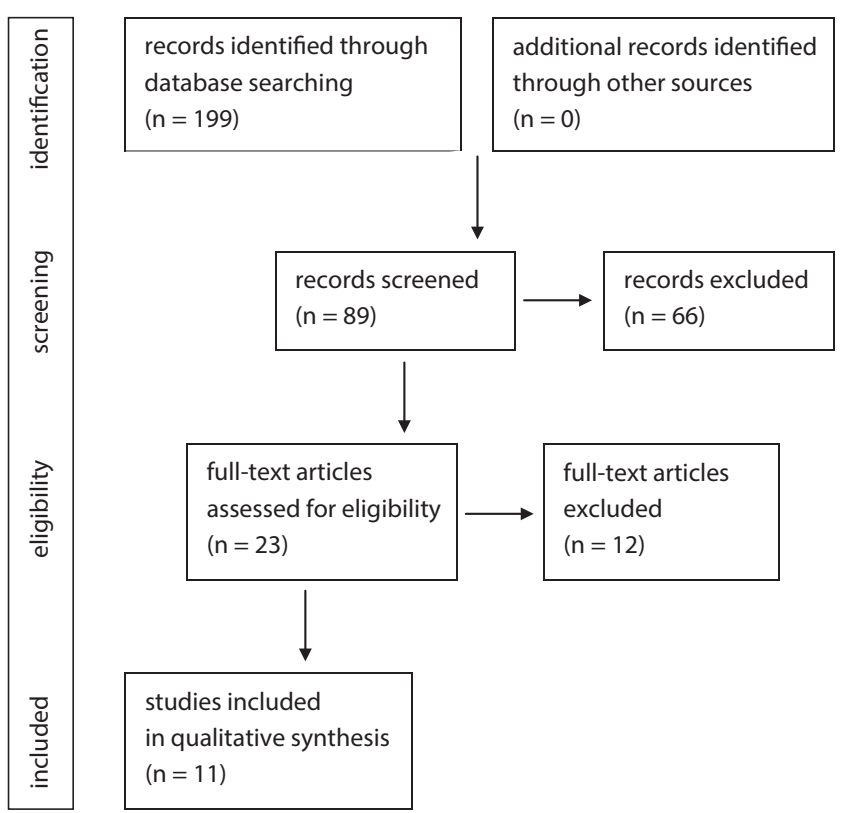

Fig. 1. Flow diagram showing the screening of studies in this systematic review 
by title; subsequently, the abstracts were read and the irrelevant studies were rejected. Data was extracted with reference to the participants, age, methods, and outcomes.

\section{Results}

The abovementioned irregularities indicate the need for complex therapy in the oral cavity. Castillo-Morales proposed a treatment for people with, i.a., muscular hypotonia and macroglossia. ${ }^{12}$ The protocol takes into account the simulating and acrylic plate, i.e., braces with a component aimed at verticalization of the tongue in the back. It is important to start the treatment early (2-3 months of age) as it reduces the negative impact on the psychosomatic development within the oral cavity. The authors refer readers who want to familiarize themselves with the above method of treatment to the article about Castillo-Morales protocol. ${ }^{12}$

Tables 2-5 set forth the results of the analysis of the material contained in the articles selected in accordance with the search strategy described in the Materials and Methods section.

\section{Discussion}

Macroglossia occurs when a tongue at rest goes beyond the dental arches or alveolar process and the alveolar part of the mandible, as in the case of edentulism. This abnormality occurs, i.a., in hypothyroidism, amyloidosis, Beckwith-Wiedemann syndrome, and DS. ${ }^{16}$ There are no clear figures that would indicate macroglossia. The division comprising the true and false form of this abnormality ${ }^{17}$ was created with regard to symptomatic treatment. Patients with $\mathrm{DS}^{11}$ have a smaller tongue $\left(2.432 \mathrm{~mm}^{2}\right)$ compared to that of the control group $\left(2.767 \mathrm{~mm}^{2}\right)$. The dimensions of the facial skeleton are also reduced, but the size of the tongue compared to bone parameters remains greater (0.54) than that of the $2^{\text {nd }}$ group $(0.46)$. Therefore, in the case of trisomy 21, false macroglossia occurs.

The potential complications of this anomaly include impaired speech, deformed mandible, malocclusion, or even airway obstruction, which is why it is important to start treatment early. The therapy includes exercise and the use of appliances which expand the dimensions of the oral cavity and (in a modified version) allow the tongue to be kept behind the dental arches. The most aggressive form of treatment is surgical treatment.

Another analyzed feature is the palate. ${ }^{13}$ Patients with DS show decreased growth and volume of the palate in the first months of life by approx. 151 days as compared to the neurotypical population, but the analyzed parameters (width and depth) remain unchanged with regard to persons with no genetic predispositions. People aged 10-40 years with DS have narrower palates, but the anteroposterior dimensions and height are similar. ${ }^{9}$ Detailed studies ${ }^{10}$ analyzed the antero-posterior length, height and volume of the hard palate as well as the size of the dental arches. The results (48 people in the study group and 48 people in the control group at the age of 6-16 years) revealed that the palate was significantly higher in patients with DS, and all other parameters were significantly lower than in the control group. Therefore, it should be concluded that narrowed gothic palate frequently occurring in older children is an acquired feature resulting from other irregularities. One of them is the aforementioned macroglossia. The results of these studies are inconclusive

Table 2. Analysis of the materials contained in the articles

\begin{tabular}{|c|c|c|c|c|c|}
\hline Author (year) & Study & Participants & Methods of outcomes & Results include & Conclusions \\
\hline $\begin{array}{l}\text { Abeleira et al. }{ }^{8} \\
(2014)\end{array}$ & $\mathrm{NRCT}$ & $\begin{array}{l}\text { SG: } 40 \text { patients with DS; } \\
\text { age: } 10-40 \text { years; } \\
\text { sex: } 25 \mathrm{M}, 15 \mathrm{~F} \\
\text { CG: age- and sex-matched } \\
\text { persons were selected }\end{array}$ & $\begin{array}{l}\text { CBCT images } \\
\text { Measurement of: } \\
\text { - overall tooth length } \\
\text { - crown height } \\
\text { - root length } \\
\text { - mesiodistal diameter } \\
\text { - vestibular-palatine diameter } \\
\text { - crown-to-root ratio } \\
\text { - cervical circumference }\end{array}$ & $\begin{array}{l}\checkmark \text { dental defects } \\
\text { o hypotonia } \\
\text { o malocclusion } \\
\text { o palate } \\
\text { o tongue } \\
\checkmark \text { skeletal defects } \\
\text { o temporomandibular joints }\end{array}$ & $\begin{array}{c}\text { Microdontia } \\
\text { of the permanent } \\
\text { teeth and progressive } \\
\text { age-related reductions } \\
\text { in tooth sizes in persons } \\
\text { with DS. }\end{array}$ \\
\hline $\begin{array}{l}\text { Abeleira et al. }{ }^{9} \\
(2015)\end{array}$ & $\mathrm{NRCT}$ & $\begin{array}{l}\text { SG: } 40 \text { patients with DS, } \\
\text { age: } 10-40 \text { years; } \\
\text { sex: } 25 \mathrm{M}, 15 \mathrm{~F} \\
\text { CG: } 40 \text { age- and sex- } \\
\text { matched persons were } \\
\text { selected }\end{array}$ & $\begin{array}{l}\text { CBCT images } \\
\text { Measurements of: } \\
\text { - anteroposterior length (aAPL) } \\
\text { - arch length } \\
\text { - anteroposterior length } \\
\text { - maximum height } \\
\text { - sagittal arch } \\
\text { - interdental width } \\
\text { - height } \\
\text { - skeletal width } \\
\text { - coronal arch }\end{array}$ & $\begin{array}{l}\text { O dental defects } \\
\text { o hypotonia } \\
\text { o malocclusion } \\
\checkmark \text { palate } \\
\text { o tongue } \\
\checkmark \text { skeletal defects } \\
\text { o temporomandibular joints }\end{array}$ & $\begin{array}{l}\text { Interdental and skeletal } \\
\text { widths were greater } \\
\text { in controls than in DS } \\
\text { statistically significant } \\
\text { differences between } \\
\text { males and females } \\
\text { with DS. }\end{array}$ \\
\hline
\end{tabular}

SG - study group; CG - control group; F - female; M - male; DS - Down syndrome; CBCT - cone-beam computed tomography; NRCT - non-randomized controlled trial; $\checkmark$ - included in research; o- not included in research. 
Table 3. Analysis of the materials contained in the articles

\begin{tabular}{|c|c|c|c|c|c|}
\hline Author (year) & Study & Participants & Methods of outcomes & Results include & Conclusions \\
\hline $\begin{array}{l}\text { Allareddy et al. }{ }^{6} \\
\text { (2016) }\end{array}$ & CS & $\begin{array}{l}27 \text { children and young } \\
\text { adults with DS; } \\
\text { age: } 3-25 \text { years }\end{array}$ & $\begin{array}{c}\text { Analysis of lateral cephalometric } \\
\text { radiographs }\end{array}$ & $\begin{array}{l}\text { O dental defects } \\
\text { o hypotonia } \\
\checkmark \text { malocclusion } \\
\checkmark \text { palate } \\
\text { o tongue } \\
\checkmark \text { skeletal defects } \\
\text { o temporomandibular joints }\end{array}$ & $\begin{array}{l}\text { Patients with DS } \\
\text { typically show skeletal } \\
\text { class III malocclusion. }\end{array}$ \\
\hline $\begin{array}{l}\text { Bhagyalakshmi } \\
\text { et al. }{ }^{10} \\
(2007)\end{array}$ & $\mathrm{NRCT}$ & $\begin{array}{l}\text { SG: } 48 \text { children with DS; } \\
\text { sex: } 26 \mathrm{M}, 22 \mathrm{~F} \\
\text { CG: } 48 \text { children } \\
\text { without DS; } \\
\text { sex: } 26 \mathrm{M}, 22 \mathrm{~F}\end{array}$ & $\begin{array}{l}\text { Electronic calipers, scale, divider, } \\
\text { dental impression material, } \\
\text { impression trays, plaster stone, } \\
\text { casting tray } \\
\text { The parameters measured were: } \\
\text { - linear width } \\
\text { - curvilinear width } \\
\text { - mean height } \\
\text { - palatal arch length } \\
\text { - anteroposterior length } \\
\text { - volume } \\
\text { - palatal index }\end{array}$ & $\begin{array}{l}\text { O dental defects } \\
\text { o hypotonia } \\
\text { o malocclusion } \\
\checkmark \text { palate } \\
\text { o tongue } \\
\checkmark \text { skeletal defects } \\
\text { o temporomandibular joints }\end{array}$ & $\begin{array}{l}\text { The hard palate } \\
\text { in children with DS was } \\
\text { found to be high- } \\
\text { arched and narrow, } \\
\text { with acutely aligned } \\
\text { palatine plates. }\end{array}$ \\
\hline $\begin{array}{l}\text { Guimaraes } \\
\text { et al. }{ }^{11} \\
(2008)\end{array}$ & $\mathrm{NRCT}$ & $\begin{array}{l}\text { CG: } 16 \text { patients with DS } \\
\text { CG: } 16 \text { age- and gender- } \\
\text { matched controls }\end{array}$ & $\begin{array}{c}\text { On sagittal and axial MR images, } \\
\text { parameters for tongue size } \\
\text { the bony craniofacial confines } \\
\text { of the retroglossal pharynx, } \\
\text { the size of the tongue relative } \\
\text { to the craniofacial bony } \\
\text { parameters. }\end{array}$ & $\begin{array}{l}\text { O dental defects } \\
\text { o hypotonia } \\
\text { o malocclusion } \\
\text { o palate } \\
\checkmark \text { tongue } \\
\checkmark \text { skeletal defects } \\
\text { o temporomandibular joints }\end{array}$ & $\begin{array}{l}\text { Children with DS do not } \\
\text { have true macroglossia } \\
\text { but have relatively large } \\
\text { tongues compared } \\
\text { to the bony confines } \\
\text { of the oral cavity. }\end{array}$ \\
\hline
\end{tabular}

SG - study group; CG - control group; F - female; M - male; DS - Down syndrome; NRCT - non-randomized controlled trial; CS - case series;

$\mathrm{SR}$ - systematic review; MR - magnetic resonance; $\checkmark$ - included in research; 0 - not included in research.

Table 4. Analysis of the materials contained in the articles

\begin{tabular}{|c|c|c|c|c|c|}
\hline Author (year) & Study & Participants & Methods of outcomes & Results include & Conclusions \\
\hline $\begin{array}{l}\text { Klimek-Jaworska } \\
\text { et al. }{ }^{12}(2014)\end{array}$ & SR & $\begin{array}{l}\text { SG }(I): 57 \text { children } \\
2 \text { months }-3 \text { years of age; } \\
\text { SG(II): } 50 \text { children } \\
3 \text { months }-5 \text { years of age }\end{array}$ & $\begin{array}{c}\text { - Reduction } \\
\text { in the severity } \\
\text { of the orbicularis oris } \\
\text { muscle hypotonia } \\
\text { - tongue position, } \\
\text { lip closure and facial } \\
\text { expression }\end{array}$ & $\begin{array}{l}\text { O dental defects } \\
\checkmark \text { hypotonia } \\
\text { o malocclusion } \\
\text { o palate } \\
\checkmark \text { tongue } \\
\text { o skeletal defects } \\
\text { o temporomandibular joints }\end{array}$ & $\begin{array}{l}\text { An early implementation of such } \\
\text { therapy facilitates the optimal } \\
\text { development of motor functions } \\
\text { of the orofacial complex. }\end{array}$ \\
\hline $\begin{array}{l}\text { Klingel et al. }{ }^{13} \\
\text { (2017) }\end{array}$ & NRCT & $\begin{array}{l}\text { SG: } 40 \text { patients with DS; } \\
\text { age: } 221.3 \pm 132.4 \text { days; } \\
\text { sex: } 20 \text { F, } 20 \mathrm{M} \\
\text { CG: } 40 \text { infants; } \\
\text { age: } 53.9 \pm 87.2 \text { days; } \\
\text { sex: } 20 \text { M, } 20 \mathrm{~F}\end{array}$ & $\begin{array}{l}\text { Width, depth and } \\
\text { length of the palate } \\
\text { were used as well } \\
\text { as the palatal index and } \\
\text { 3-dimensional volume. }\end{array}$ & $\begin{array}{l}\text { O dental defects } \\
\text { o hypotonia } \\
\text { o malocclusion } \\
\checkmark \text { palate } \\
\text { o tongue } \\
\checkmark \text { skeletal defects } \\
\text { o temporomandibular joints }\end{array}$ & $\begin{array}{l}\text { The palate of DS infants in the first } \\
6 \text { to } 9 \text { months of life is normally } \\
\text { shaped but considerably smaller } \\
\text { compared to healthy individuals. }\end{array}$ \\
\hline $\begin{array}{l}\text { Nęcka et al.7 } \\
\text { (2007) }\end{array}$ & $\mathrm{NRCT}$ & $\begin{array}{c}\text { SG: } 22 \text { patients with DS } \\
\text { CG: } 23 \text { persons with } \\
\text { hypotonia }\end{array}$ & $\begin{array}{l}\text { Electromyography } \\
\text { of mimic and } \\
\text { mastication muscles } \\
\text { tone }\end{array}$ & $\begin{array}{l}\text { O dental defects } \\
\checkmark \text { hypotonia } \\
\text { o malocclusion } \\
\text { o palate } \\
\text { o tongue } \\
\text { o skeletal defects } \\
\text { o temporomandibular joints }\end{array}$ & $\begin{array}{c}\text { No significant differences } \\
\text { between the tonus of temporal } \\
\text { and masticatory muscles } \\
\text { of people suffering from DS; } \\
\text { no statistically significant } \\
\text { differences were observed } \\
\text { during the orbicular muscles } \\
\text { examination. }\end{array}$ \\
\hline
\end{tabular}

SG - study group; CG - control group; F - female; M - male; DS - Down syndrome; NRCT - non-randomized controlled trial; SR - systematic review; $\checkmark$ - included in research; 0 - not included in research.

as to the reduced parameters of the palate, but all results point to the reduction of its volume. Considering the determinants of development, which include environmental impact, quality of life, lifestyle, and national differences, it should be noted that the narrow gothic palate often found in older children is an acquired feature. This causes disorders, the most serious of which is hypoxia.

People with trisomy 21 often have disorders of the stomatognathic system. These include the following: hypoplasia, diastema, mandibular prognathism, anterior open bite, 
Table 5. Analysis of the materials contained in the articles

\begin{tabular}{|c|c|c|c|c|c|}
\hline Author (year) & Study & Participants & Methods of outcomes & Results include & Conclusions \\
\hline $\begin{array}{l}\text { Oliveira et al. }{ }^{5} \\
(2008)\end{array}$ & CS & $\begin{array}{l}112 \text { pairs of mothers and } \\
\text { their children with DS; } \\
\text { age: } 3-18 \text { years }\end{array}$ & $\begin{array}{l}\text { Data was collected with } \\
\text { a questionnaire given to the mothers } \\
\text { and through a clinical examination } \\
\text { of the child or adolescent. Univariate, } \\
\text { bivariate and multiple logistic } \\
\text { regression (backward stepwise) } \\
\text { analyses were conducted. }\end{array}$ & $\begin{array}{l}\text { O dental defects } \\
\text { o hypotonia } \\
\checkmark \text { malocclusion } \\
\text { o palate } \\
\text { o tongue } \\
\checkmark \text { skeletal defects } \\
\text { o temporomandibular joints }\end{array}$ & $\begin{array}{l}\text { Age, nail or finger } \\
\text { biting, mouth } \\
\text { posture, and upper } \\
\text { airway infections } \\
\text { were associated } \\
\text { with malocclusions } \\
\text { in these patients. }\end{array}$ \\
\hline $\begin{array}{l}\text { Salazar et al. }{ }^{14} \\
(2016)\end{array}$ & CS & 40 patients with DS & $\begin{array}{l}\text { temporomandibular joint } \\
\text { examination }\end{array}$ & $\begin{array}{l}\text { o dental defects } \\
\text { o hypotonia } \\
\text { o malocclusion } \\
\text { o palate } \\
\text { o tongue } \\
\text { o skeletal defects } \\
\checkmark \text { temporomandibular joints }\end{array}$ & $\begin{array}{c}\text { The relationship } \\
\text { between habits } \\
\text { and pain in people } \\
\text { with DS. }\end{array}$ \\
\hline $\begin{array}{l}\text { Tosello et al. }{ }^{15} \\
\text { (2002) }\end{array}$ & $\mathrm{NRCT}$ & $\begin{array}{l}18 \text { children; } \\
\text { age: } 8 \text {-12 years; } \\
\text { divided into } 3 \text { groups: } \\
\text { 1. normal occlusion } \\
\text { 2. class II division } 1 \\
\text { 3. atypical swallowing } \\
\text { and/or incompetent lips }\end{array}$ & $\begin{array}{l}\text { electromyographically in resting } \\
\text { position and in several movements }\end{array}$ & $\begin{array}{l}\text { O dental defects } \\
\checkmark \text { hypotonia } \\
\checkmark \text { malocclusion } \\
\text { o palate } \\
\text { o tongue } \\
\checkmark \text { skeletal defects } \\
\text { o temporomandibular joints }\end{array}$ & $\begin{array}{l}\text { The } 3^{\text {rd }} \text { group } \\
\text { showed very } \\
\text { marked activity } \\
\text { of the lower } \\
\text { orbicularis oris and } \\
\text { mentalis muscles. }\end{array}$ \\
\hline
\end{tabular}

DS - Down syndrome; NRCT - non-randomized controlled trial; CS - case series; $\checkmark$ - included in research, o - not included in research.

lip incompetence, and deepened overbite. Temporomandibular joint dysfunction in patients with DS was found in $77.5 \%$ of patients. ${ }^{14}$ Malocclusion occurred in $66 \%$ of patients, ${ }^{18}$ with the dominance of skeletal class III defects. Taking into account the cephalometric analysis, ${ }^{6}$ it is dominated by the skeletal class III and increased proportion of the lower part of the face with regard to the overall height, wherein the skeletal class III is more clearly indicated in the older age groups. Analysis of incisors, ${ }^{8}$ canines and first molars, i.e., the length of the tooth, crown height and root length, tooth neck perimeter, mesiodistal width, buccolingual dimension, and the ratio between the crown height and root length, with the use of computed tomography, draws attention to the reduction in tooth dimensions while the ratio between the crown height and root length is maintained; no sexual dimorphism was found (only the length of the roots of the incisors remains greater in men). Crown height, mesiodistal diameter and the ratio between the crown and the root gradually decrease with age. This confirms microdontia in patients with trisomy 21 .

Muscular hypotonia in persons with DS affects the whole organism. An analysis ${ }^{7}$ of temporal muscles $(\mathrm{L} / \mathrm{R})(\mathrm{L}=\mathrm{left}$, $\mathrm{R}=$ right), masseter muscles (L/R) and orbicularis oris muscles with the use of an electromyograph during various physiological functions, i.e., swallowing, chewing, rest position of the mandible, position of the lips as for whistling, maximum intercuspation, indicates significantly higher tension of the orbicularis oris muscle in children with DS compared to the neurotypical group and no statistical differences for the temporal and masseter muscles. At the same time, during the physical examination, insufficiency of the orbicularis oris muscle is clearly expressed, which is contrary to the electromyography (EMG) indication. Careful analysis reveals an increase in the tension of the orbicularis oris muscle when the lips are positioned for whistling, while higher signals on the measuring device result from the conscious tightening of muscles by the patient.

Comparing this data with the results of studies on 3 groups $^{15}$ :

1. persons with malocclusions,

2. persons with persistent visceral swallowing,

3. persons with lip incompetence,

who did not undergo orthodontic treatment, in the case of joined lips, the EMG shows higher muscle potential in group 3 and high muscle activity while sucking a lollipop, with no differences between the subgroups while sucking a dummy, a straw or a thumb. This indicates a conscious tightening of fibers, which confirms the abovementioned data.

\section{Conclusions}

People with DS have different craniofacial morphology. The treatment plan should take into account the occurrence of false macroglossia, dental irregularities, hypoplasia, and diastema. A well-arched gothic palate is an acquired feature, thus orthodontic activities should prevent the development of this anomaly. Attention should be paid to the reduced tension of the orbicularis oris muscle, which, in conjunction with false macroglossia, affects the incidence of anterior open bite.

Although macroglossia, hypotonia, malocclusion, and temporomandibular joint abnormalities are not features exclusive to DS, numerous dysfunctions and parafunctions as well as retarded psychomotor development greatly complicate the treatment. Therefore, interdisciplinary 
treatment of patients with trisomy 21 and early treatment in the first months of life with the use of the Castillo-Morales plate are very important, as they ensure better adaptation to the subsequently used apparatus and reduce the risk of disorders of the stomatognathic system in the future.

\section{ORCID iDs}

Natalia Kaczorowska (1) https://orcid.org/0000-0003-4270-6143

Kamil Kaczorowski (1) https://orcid.org/0000-0002-1357-1553

Joanna Laskowska (1) https://orcid.org/0000-0001-9207-9067

Marcin Mikulewicz (D) https://orcid.org/0000-0001-5754-0284

\section{References}

1. De Graaf G, Buckley F, Skotko BG. Estimates of the live births, natural losses, and elective terminations with Down syndrome in the United States. Am J Med Genet A. 2015;167(4):756-767.

2. Ferrario VF, Dellavia C, Colombo A. Three-dimensional assessment of nose and lip morphology in subjects with Down syndrome. Ann Plast Surg. 2004;53(6):577-583.

3. Townsend GC. Tooth size in children and young adults with trisomy 21 (Down) syndrome. Arch Oral Biol. 1983;28(2):159-166.

4. Sakellari D, Arapostathis KN, Konstantinidis A. Periodontal conditions and subgingival microflora in Down syndrome patients. J Clin Periodontol. 2005;32(6):684-690.

5. Oliveira ACB, Paiva SM, Campos MR, Czeresnia D. Factors associated with malocclusions in children and adolescents with Down syndrome. Am J Orthod Dentofacial Orthop. 2008;133(4):489.e1-8.

6. Allareddy V, Ching N, Macklin EA, et al. Craniofacial features as assessed by lateral cephalometric measurements in children with Down syndrome. Prog Orthod. 2016;17(1):35.

7. Nęcka A, Kawala B, Matthews-Brzozowska T. Evaluation of facial muscle tone using surface electromyography in children with Down syndrome. Ann Acad Med Stetin. 2007;53(3):98-101.
8. Abeleira MT, Outumuro M, Ramos I, Limeres J, Diniz M, Diz P. Dimensions of central incisors, canines, and first molars in subjects with Down syndrome measured on cone-beam computed tomographs. Am J Orthod Dentofacial Orthop. 2014;146(6):765-775.

9. Abeleira MT, Outumuro M, Diniz M, Limeres J, Ramos I, Diz P. Morphometry of the hard palate in Down's syndrome through CBCTimage analysis. Orthod Craniofac Res. 2015;18(4):212-220.

10. Bhagyalakshmi G, Resanukarya AJ, Rajangam S. Metric analysis of the hard palate in children with Down syndrome: A comparative study. Downs Syndr Res Pract. 2007;12(1):55-59.

11. Guimaraes CV, Donnelly LF, Shott ES, Amin RS, Kalra M. Relative rather than absolute macroglossia in patients with Down syndrome: Implications for treatment of obstructive sleep apnea. Pediatr Radiol. 2008;38(10):1062-1067.

12. Klimek-Jaworska K, Wyszomirska-Zdybel B. The application of a stimulating palatal plate as designed by Castillo-Morales in the treatment of children with Down syndrome: A review of available literature. Orthod Forum. 2014;10(4):279-286.

13. Klingel D, Hohoff A, Kwiecien R, Wiechmann D, Stamm T. Growth of the hard palate in infants with Down syndrome compared with healthy infants: A retrospective case control study. PLoS One. 2017; 13(9):1-10.

14. Salazar AP, Nery JC, Donini L, Paim Nora V, Rizzo Nique Peralles S. Temporomandibular joint evaluation in subjects with Down syndrome [in Spanish]. International Medical Review on Down Syndrome. 2016;20(3):39-42.

15. Tosello DO, Vitti M, Berzin F. EMG activity of the orbicularis oris and mentalis muscles in children with malocclusion, incompetent lips and atypical swallowing: Part I. J Oral Rehabil. 2002;25(11):838-846.

16. Weiss LS, White JA. Macroglossia: A review. J La State Med Soc. 1990; 142(8):13-16.

17. Vogel JE, Mulliken JB, Kaban LB. Macroglossia: A review of the condition and a new classification. Plast Reconstr Surg. 1986;78(6):715-723.

18. Alkhadra T. Characteristic of malocclusion among Saudi special need group children. J Contemp Dent Pract. 2017;18(10):959-963. 